\title{
Transplanting Palms
}

\section{Donald R. Hodel ${ }^{1,4}$, A. James Downer ${ }^{2}$, and Dennis R. Pittenger ${ }^{3}$}

ADDITIONAL INDEX WORDs. backfill amendment, handling, irrigation, leaf removal, tie-up, mulch, planting depth, plant maturity, root ball size, time of year, transport, water loss

SUMMARY. The optimum time to transplant palms (Arecaceae) is at the beginning of the warm season in temperate climates or at the beginning of the rainy season in tropical climates if irrigation is unavailable. Careful and proper handling, including covering and protecting the leaves and root ball during transplanting to protect them from injury and drying out and immediate planting upon arrival at the new site, helps to ensure rapid and successful establishment. A root ball extending out from the trunk for $30 \mathrm{~cm}$ appears to be adequate for most solitary-stemmed species. Larger root balls may be necessary for multistemmed or unusually tall or large specimens. Tying up leaves facilitates handling during digging, transport, and planting, but it is best to untie them after planting. In most instances leaf removal during transplanting does not appear to be advantageous, and it is probably best to remove leaves only when they die and turn brown. Too deep or too shallow planting lowers transplant success and stresses palms, making them susceptible to diseases, disorders, and pests. Amending the backfill when transplanting palms is not beneficial in most cases. However, mulch applied around the base of the palm after transplanting can enhance growth. Keeping the soil, backfill, and surrounding site soil evenly moist helps to ensure successful establishment.

$\mathrm{T}$ he root system of palms is adventitious and composed of numerous, small- to mediumsized, nonwoody roots. All primary roots are of a more or less constant diameter and arise independently from an area at or near the base of the stem called the root initiation zone (RIZ) (Tomlinson, 1990). Because of these root system characteristics and the ability of their trunks to store water and carbohydrates (Tomlinson, 1990), palms are relatively easy to transplant-even large specimens with small root ballsresulting in instant, mature landscapes. In contrast, the woody, branched root systems of dicotyledonous and coniferous trees require that a much larger root ball be secured to ensure establishment of these types of trees, increasing the difficulty and expense of transplanting large specimens.

The basic element of successful establishment of transplanted palms is the rapid generation of new roots from the RIZ and/or the regeneration of new root tips from cut existing

\footnotetext{
${ }^{1}$ University of California Cooperative Extension, 4800 East Cesar Chavez Avenue, Los Angeles, CA 90022

${ }^{2} 669$ County Square Drive, Suite 100, Ventura, CA 93003

${ }^{3}$ Department of Botany and Plant Sciences, University of California, Riverside, CA 92521

${ }^{4}$ Corresponding author. E-mail: drhodel@ucdavis. edu.
}

roots. A number of important factors, such as plant maturity, the time of year, root ball size, leaf removal and tie-up, planting depth, the use of soil amendments in the backfill, mulching, and irrigation management, can influence the success of palm transplanting.

For clarity, we define transplanting in this article as the digging of palms in the landscape or field production nursery and then planting them into the new landscape. Typically, transplanting palms results in a significant reduction of their root system, and the process generally requires special handling practices to ensure successful establishment and survival. In contrast, planting containerized palms, where the root system is mostly intact, results in little or no root loss or disturbance, and is a much simpler and less exacting process. Although this article primarily addresses issues relating to transplanting palms, many of the factors presented and discussed below can also affect establishment of containerized palms.

Readers are encouraged to consult Broschat and Meerow (2000) and Pittenger et al. (2005) for well- illustrated accounts of the industry practices presented and discussed here.

\section{Plant maturity}

The age of the palm and development of its RIZ are critical factors in root regeneration and can affect successful transplanting of some species. Broschat and Donselman (1990a) found that in the pygmy date palm (Phoenix roebelinii) and parlor palm (Chamaedorea elegans), root regeneration was dependent on the RIZ being fully developed, which occurred only after the stem had attained its maximum diameter and was elongating vertically. However, a fully developed RIZ may not be essential for successful transplanting of juvenile plants of some species, including coconut palm (Cocos nucifera), canary island date palm (Phoenix canariensis), queen palm (Syagrus romanzoffiana), and off shoots of date palm (Phoenix dactylifera), where cut roots have high survival rates (Broschat and Meerow, 2000; Hodel and Pittenger, 2003; Hodel et al., 2003).

\section{Time of year}

Because palm leaf and root growth are highly correlated with air and soil temperatures (Broschat and Meerow, 2000) and are most rapid during the warmer months (Broschat, 1998; Hodel et al., 2005), it is best to transplant palms at the beginning of the warm season to ensure as long a period as possible of active and sustained growth. In subtropical and temperate areas with seasonal growth fluctuations, such as the southwestern United States and areas with a Mediterranean climate, the best time to transplant palms is in late spring, just before or at the beginning of accelerated summer growth (Hodel et al., 2005). In the northern hemisphere, this period would include the months of March to June, depending on the location.

Palms transplanted in late fall and winter will have little root growth, and establishment will be slow,

\begin{tabular}{llll}
\hline $\begin{array}{l}\text { Units } \\
\begin{array}{l}\text { To convert U.S. to SI, } \\
\text { multiply by }\end{array}\end{array}$ & U.S. unit & SI unit & $\begin{array}{l}\text { To convert SI to U.S., } \\
\text { multiply by }\end{array}$ \\
\hline 0.3048 & $\mathrm{ft}$ & $\mathrm{m}$ & 3.2808 \\
2.54 & inch $(\mathrm{es})$ & $\mathrm{cm}$ & 0.3937
\end{tabular}


stressing the palm and leaving it vulnerable to diseases, pests, and disorders (Broschat and Meerow, 2000). While it is possible to transplant and plant palms successfully in the late fall and winter, the chances for failure increase if transplanting is done during this time.

In more tropical regions without seasonal temperature fluctuations and where growth is more or less constant throughout the year, such as southern Florida and Hawaii, palms can be transplanted year round (Broschat and Meerow, 2000). However, if rain is seasonal and irrigation lacking, palms are best transplanted at the beginning of the rainy season (Broschat and Meerow, 2000).

\section{Leaf removal and tie-up}

Removal of some of the leaves (typically at least half or more) and cutting back and tying up the remainder are standard, yet nonetheless, controversial industry practices when transplanting palms. They purportedly reduce water loss and keep the palm from drying out until new roots grow. They also purportedly protect the center bud and facilitate handling during digging, transport, and planting. Leaf removal and tie-up, though, are unpleasing esthetically and may not be beneficial to transplanted palms in most cases.

While leaf removal and tie-up do reduce water loss initially, a few weeks after transplanting, these practices may become less effective in reducing water loss in some species, such as canary island date palm and queen palm, thus casting doubt on their importance to successful palm transplanting (D.R. Hodel, unpublished data). It is possible that palms have some mechanism (perhaps closing stomata) for reducing water loss when water stressed, such as during transplanting, and can rely on water stored in the trunk and/or other tissue until adequate root growth occurs.

Broschat (1994) showed that pygmy date palms had increased root and shoot growth and higher survival rates when leaves were not removed during transplanting as long as root balls were kept moist. In other studies, there was no effect of leaf removal and/or tie-up on new root growth and leaf production or survival during transplanting juvenile queen palms and canary island date palms and large mexican fan palms (Washingtonia robusta) (Hodel et al., 2003, 2006a; A.J. Downer, D.R. Hodel, D.R. Pittenger, and M.J. Mochizuki, unpublished data). In these latter studies, the only benefit of leaf removal appeared to be improvement of esthetic quality by removal of leaves that might have turned brown and died later anyway.

Thus, leaf removal and tie-up may be largely unnecessary when transplanting most palms. While tieup facilitates handling during digging, transport, and planting, it is best to untie leaves once the palm is planted. Because there may be instances when no leaves turn brown and die during transplanting, and a full contingent of green, functioning leaves would enhance growth and establishment, it is probably most prudent to refrain from early leaf removal, and only remove leaves for esthetic reasons once they die and turn brown. However, complete leaf removal improves survival and establishment in the few species that must generate an entirely new root system when transplanted, such as the sabal palm (Sabal palmetto) (Broschat, 1991; Costonis, 1995).

\section{Root ball size}

While the adage "the larger the root ball the better" may have some merit for transplant success, in practical terms, optimal root ball size is a compromise between root regeneration and the feasibility and economics of digging, transporting, and planting a palm with an exceedingly large, heavy root ball (Broschat and Meerow, $2000)$. The ability of palm roots to regenerate when cut was once thought to be the most critical factor in determining root ball size and transplant success (Broschat and Donselman, 1984a, 1984b, 1990b), and it still may be useful for some species, especially those with low root regeneration from the RIZ but high root regeneration from cut roots. However, Pittenger et al. (2005) concluded that the total number and density of roots, rather than their origin (from the RIZ or from cut roots that regenerated), were the key factors determining the optimal root ball size for transplanting many palms.

Root balls extending out from the trunk for $30 \mathrm{~cm}$ and to $30 \mathrm{~cm}$ deep are adequate for most species
(Hodel et al., 2005) because they typically capture a sufficient number of cut roots to regenerate and continue growing and/or offer protection of the RIZ for newly generated roots. Meerow and Broschat (1992) had similar recommendations, with root balls extending out from the trunk for 8 inches for palms to $16 \mathrm{ft}$ tall and 12 inches for larger or multitrunked palms.

Deeper root balls may be advantageous for some species, such as the bismarck palm (Bismarckia nobilis), whose roots typically show a more downward rather than lateral growth trend (Broschat and Meerow, 2000), and other, especially large specimens, to help to ensure adequate anchorage.

In a few species, such as the sabal palm, all roots cut when transplanting dieback to the trunk, and the palm must generate an entirely new root system to establish successfully (Broschat and Donselman, 1984a). In these cases, the root ball need only be sufficiently large to protect the RIZ during the transplanting process and provide weight for anchorage and stability.

\section{Digging palms}

Irrigate the soil thoroughly several days before digging to ensure optimal water status of the palm and maximum soil adhesiveness (Broschat and Meerow, 2000). Leaves can be tied up for protection and to facilitate handling during transplanting. In some instances, support and protection of the apical meristem and unopened "spear" leaves with bracing or splints securely attached to the trunk and extending into the leaves during digging and transport may be prudent measures to prevent excessive movement, which can damage these fragile organs and impede or prevent establishment and survival (Broschat and Donselman, 1987).

Palms can be dug by hand, using spades, or with powered, mechanized backhoes or trenchers (Broschat and Meerow, 2000). Some industry sources in California favor a sharp spade over a trencher or backhoe when excavating palms (or at least when making the final cut on the trench wall facing the palm) because the former make a neat, clean cut while the latter tend to tear or shred roots. These sources assert that neatly cut 
roots are more likely to regenerate than torn and shredded roots. However, this assertion proved to be untrue with the chinese fountain palm (Livistona chinensis) and king palm (Archontophoenix cunninghamiana) (D.R. Hodel, A.J. Downer, and D.R. Pittenger, unpublished data). Some sources also contend that cauterizing freshly cut root tips with a torch to prevent moisture loss from their damaged surfaces enhances establishment and survival of transplanted palms, although there is no research to support this practice.

Protect root balls of palms growing in light sandy soils, which are susceptible to crumbling and falling apart when disturbed, by securely wrapping them in burlap (Broschat and Meerow, 2000) or in multiple layers of self-adhesive polyethylene film during digging and transport (if clear polyethylene film is used, shade the root ball during transport and before planting because the sun can heat the soil inside the film to levels that can damage roots). Even for palms growing in heavier, more adhesive soils, it is best to wrap root balls securely for lengthy or rough transport. Once dug, wrapped, and secured, root balls can be easily undercut by placing a loop of self-cinching cable in the base of the trench around the root ball and pulling or drawing it tightly with a tractor.

Because of their weight, cranes are usually needed to lift most palms. While it is best to lift palms from below the root ball, this method is usually not practical and it may be easiest to attach directly to the trunk. In these cases, the trunk should be protected with burlap, carpet, or similar material and a webbed, selfcinching sling used for attachment to the trunk. Smaller palms with lighter root balls can be removed by excavating a ramp into the hole, placing the root ball on a heavy duty dolly, and simply pulling it up and out of the hole.

\section{Transport and handling}

Proper handling during the digging, transporting, and planting processes is critical for successful establishment of transplanted palms (Broschat and Meerow, 2000). Carefully load and secure palms to avoid damaging or wounding the palm, especially the trunk and apical meristem, during transport. Generally, it is best to place root balls forward and leaves toward the rear. A support may be necessary under the distal portion of the trunk near the leaf crown to prevent undue pressure from the sheer weight of the palm or adjacent palms on the apical meristem and newly emerging leaves. Protect leaves and root balls from wind and drying out by covering the entire palm with shadecloth during transport. For lengthy transport, it may be necessary to moisten root balls periodically.

If planting must be delayed, store palms in the shade and cover and protect leaves and root balls with shadecloth and keep root balls moist until planting (Broschat and Meerow, 2000). In some instances, consider heeling-in root balls for added protection and to help retain moisture (Broschat and Meerow, 2000).

Control the planting site to ensure that drainage is good and not impeded. Poor drainage and/or excessive irrigation are detrimental to root growth and can result in numerous problems, including transplant failure (Broschat and Donselman, 1987; Broschat and Meerow, 2000).

\section{Planting and planting depth}

Palm roots need abundant oxygen to grow and develop adequately. A planting hole only as deep as the root ball but twice as wide is recommended (Broschat and Meerow, 2000). Planting too deep (or even too high) can reduce root growth and adversely affect establishment of transplanted palms (Broschat, 1995; Broschat and Meerow, 2000). For rapid and successful establishment, plant palms at grade, with the top of the root ball even with the surrounding level of site or native soil. While deep planting to achieve uniform height in more formal, multipalm plantings, such as those lining streets or entryways, is a fairly common industry practice with some species, like the mexican fan palm, it increases the chances for failure. Such deeply planted palms often show a lack of vigor or may suffer from chronic nutritional deficiencies if they survive (Broschat, 1995; Broschat and Meerow, 2000).

Firmly tamp the backfilled soil to remove all air pockets and then flood irrigate several times to ensure proper settling of the soil. External support bracing of trunks using wood or cable guying, taking care not to damage or wound the trunk, may be necessary in areas of frequent high winds or when root balls lack sufficient mass to provide adequate anchorage and stability (Broschat and Meerow, 2000).

\section{Amending the backfill}

Adding organic material to the backfill when transplanting or planting palms is a common industry practice. However, this practice has generally not been shown to be beneficial and is not recommended (Meerow and Broschat, 1992). Hodel et al. (2006b) found that amending the backfill did not increase leaf production, stem diameter, crown volume, leaf quality or nutrient composition, or survival when planting five species of common landscape palms. In most cases, plant palms using the same soil that came out of the planting hole as backfill. However, incorporation of thoroughly decomposed, nitrogen-stabilized organic material may be beneficial in extremely rocky substrates with little or no water- and nutrient-holding capacity (Broschat and Meerow, 2000).

Another common practice, especially in California and the southwestern United States, is to use builder's sand as the sole backfill material when transplanting palms. There is no research to support this practice, which purportedly promotes drainage and aeration and enhances anchorage, resulting in superior root growth and faster establishment. However, work in the preliminary stages (D.R. Hodel, A.J. Downer, and D.R. Pittenger, unpublished data) appears to cast doubt on its horticultural benefits.

\section{Mulching}

While amending the backfill with organic matter has not been beneficial when transplanting or planting most palms, the use of organic mulches around the base of the palm can be beneficial. Downer and Hodel (2001) recommend applying a 5- to 8-cm layer of decomposed, nitrogen-stabilized mulch around the base of newly planted palms. This mulch will help to conserve water, inhibit weeds, improve soil structure, hold nutrients, and enhance the environment for root growth. 
Applying mulch or soil directly against the trunk may be beneficial in instances where roots emerging from the RIZ fail to reach the soil, a condition known as inverted root cone (Hodel, 2008). Too shallow planting, errant monofilament weed trimmers, and, at least in California, arid conditions that effectively "air-prune" emerging roots can cause inverted root cone. However, if mulch is used, it must be regularly replenished because it will shrink and settle with oxidation, pulling away from the trunk and exposing any roots that may have begun to grow into it but have not yet reached the soil.

\section{Irrigation management}

Irrigation management is one of the most critical factors affecting palm transplant success. Many transplanted palms are lost due to insufficient or excessive irrigation. The primary strategy is to maintain the root ball, backfill, and surrounding site soil evenly moist (Broschat and Meerow, 2000; Pittenger et al., 2005). Manual and visual inspection is necessary to determine soil moisture. Irrigate transplanted palms when they need it, not by a calendar or clock. Apply sufficient water at each irrigation to moisten the entire root ball or the soil to $30 \mathrm{~cm}$ deep, whichever is greater.

\section{Other practices}

There are other practices or factors that can affect establishment of transplanted palms. Root pruning before excavating the palm for transplanting, purportedly to stimulate the production of new roots, is sometimes done, but there is no research to support this practice. Even if root pruning does stimulate production of new roots, they would be vulnerable to serious damage during the digging, transporting, and planting processes.

While the use of plant growth regulators to stimulate root growth is a common practice with many woody plants, their use on palms during transplanting has little or no merit. Although there is little research on the subject, Broschat and Donselman (1990a) showed that the application of root-promoting substances to the roots of transplanted parlor palms and pygmy date palms had no effect on root growth.

Because transplanting stresses palms, monitor transplanted palms carefully for secondary problems, such as pest infestations, diseases, and abiotic disorders, and treat appropriately.

\section{Literature cited}

Broschat, T.K. 1991. Effects of leaf removal on survival of transplanted Sabal palms. J. Arboriculture 17:32-33.

Broschat, T.K. 1994. Effects of leaf removal, leaf tying, and overhead irrigation on transplanted pygmy date palms. J. Arboriculture 20:210-213.

Broschat, T.K. 1995. Planting depth affects survival, root growth, and nutrient content of transplanted pygmy date palms. HortScience 30:1031-1032.

Broschat, T.K. 1998. Root and shoot growth patterns in four palm species and their relationships with air and soil temperatures. HortScience 33:995-998.

Broschat, T.K. and A.W. Meerow. 2000. Ornamental palm horticulture. University Press of Florida, Gainesville, FL.

Broschat, T.K. and H. Donselman. 1984a. Regrowth of severed palm roots. J. Arboriculture 10:238-240.

Broschat, T.K. and H. Donselman. 1984b. Root regeneration in transplanted palms. Principes 28:90-91.

Broschat, T.K. and H. Donselman. 1987. Factors affecting palm transplant success. Proc. Florida State Hort. Soc. 100:396397.

Broschat, T.K. and H. Donselman. 1990a. IBA, plant maturity, and regeneration of palm root systems. HortScience 25:232.

Broschat, T.K. and H. Donselman. 1990b. Regeneration of severed roots in Washingtonia robusta and Phoenix reclinata. Principes 34:96-97.
Costonis, A.C. 1995. Factors affecting survival of transplanted Sabal palms. J. Arboriculture 21:98-102.

Downer, A.J. and D.R. Hodel. 2001. The effects of mulching on establishment of Syagrus romanzoffiana (Cham.) Becc., Washingtonia robusta $\mathrm{H}$. Wendl. and Archontophoenix cunninghamiana (H. Wendl.) H. Wendl. and Drude in the landscape. Scientia Hort. 87:85-92.

Hodel, D.R. 2008. Palms in the landscape: Palm biology and implications for management. Part 3. Western Arborist 34(4):14-22.

Hodel, D.R. and D.R. Pittenger. 2003. Studies on the establishment of date palm (Phoenix dactylifera 'Deglet Noor') offshoots. Part I: Observations on root development and leaf growth. Palms 47:191-200.

Hodel, D.R., A.J. Downer, and D.R. Pittenger. 2006a. Effect of leaf removal and tie up on transplanted large mexican fan palms (Washingtonia robusta). Palms 50:76-81.

Hodel, D.R., A.J. Downer, D.R. Pittenger, and P. Beaudoin. 2006b. Effect of amended backfill soils when planting five species of palms. HortTechnology 16: $457-460$

Hodel, D.R., D.R. Pittenger, A.J. Downer, and W.E. Richie. 2003. Effect of leaf removal and tie up on juvenile, transplanted canary island date palms (Phoenix canariensis) and queen palms (Syagrus romanzoffiana). Palms 47:177184.

Hodel, D.R., D.R. Pittenger, and A.J. Downer. 2005. Palm root growth and implications for transplanting. J. Arboriculture 31:171-181.

Meerow, A.W and T.K Broschat. 1992. Transplanting palms. Univ. Florida Coop. Ext. Serv. Circ. 1047.

Pittenger, D.R., D.R. Hodel, and A.J. Downer. 2005. Transplanting specimen palms: A review of common practices and research-based information. HortTechnology 15:128-132.

Tomlinson, P.B. 1990. The structural biology of palms. Oxford University Press, New York. 